Goldschmidt 2021 Abstract

https://doi.org/10.7185/gold2021.6775

\section{Coherent Tracer Correlations in Deep-sea Corals and Implications for Biomineralization Mechanisms underlying Vital Effects}

\author{
SANG CHEN ${ }^{1}$, ELOISE F.M. LITTLEY ${ }^{2}$, JAMES W. B. \\ RAE $^{2}$, CHRIS CHARLES ${ }^{3}$, YUNBIN GUAN ${ }^{4}$ AND JESS \\ ADKINS $^{4}$
}

${ }^{1}$ Shanghai Jiao Tong University

${ }^{2}$ University of St Andrews

${ }^{3}$ Scripps Institute of Oceanography

${ }^{4}$ California Institute of Technology

Presenting Author: sang@sjtu.edu.cn

Deep-sea corals are a useful archive of thermocline, intermediate, and deep waters in past oceans. However, application of traditional tracers to deep-sea corals remains a challenge due to our insufficient understanding of their "vital effects". Deep-sea corals are ideal test organisms to study the mechanisms underlying vital effects generally, due to the large tracer gradients in individual corals living under relatively constant environmental conditions. Here we present stable isotope, minor and trace metal (Me/Ca ratios) data in a suite of modern Desmophyllum dianthus specimens, collected over multiple spatial scales in individual corals (bulk, micromill, SIMS, nanoSIMS). Spatially coherent $\mathrm{Me} / \mathrm{Ca}$ correlations are observed in the fibrous aragonite of individual corals, including positive correlations between $\mathrm{Mg} / \mathrm{Ca}, \mathrm{Li} / \mathrm{Ca}$ and $\mathrm{B} / \mathrm{Ca}$, as well as negative correlations between $\mathrm{Mg} / \mathrm{Ca}$ and $\mathrm{Sr} / \mathrm{Ca}$, consistent with previous studies. We also for the first time document strong correlations between the isotopic $\left(\delta^{18} \mathrm{O}\right.$ and $\left.\delta^{13} \mathrm{C}\right)$ and elemental compositions of the skeletons, most notably a negative correlation between $\delta^{18} \mathrm{O}$ and $\mathrm{Mg} / \mathrm{Ca}$ and a positive correlation between $\delta^{18} \mathrm{O}$ and $\mathrm{U} / \mathrm{Ca}$. The centers of calcification (COCs) in the coral skeletons show distinct tracer correlations from the fibrous aragonite. We interpret the spatially coherent tracer correlations in deep-sea corals with a numerical model of coral calcification previously developd for the stable isotopes that considers the role of the enzyme carbonic anhydrase in the calcification processs. With the carbonate chemistry in the model constrained by the stable isotope data, we are able to explain the observed $\mathrm{Me} / \mathrm{Ca}$ correlations as well as their range of variability, as a result of internal $\mathrm{pH}$ elevation in the extracellular calcifying fluid (ECF) of the corals with limited Ca-pumping through the membrane. In particular, the positive $\mathrm{Mg} / \mathrm{Ca}-\mathrm{B} / \mathrm{Ca}$ correlation in the secondary aragonite suggests a borate $\left(\mathrm{B}(\mathrm{OH})_{4}^{-}\right)$for carbonate ion $\left(\mathrm{CO}_{3}{ }^{2-}\right)$ incorporation mechanism in biogenic aragonite. In addition, we find a reduction in tracer variability in corals from undersaturated seawater as opposed to their counterparts from supersaturated conditions, suggesting a limited amount of internal $\mathrm{pH}$ elevation in response to the environmental stress.

Deep-sea corals are a useful archive of thermocline, intermediate, and deep waters in past oceans. However, application of traditional tracers to deep-sea corals remains a challenge due to our insufficient understanding of their "vital effects". Deep-sea corals are ideal test organisms to study the mechanisms underlying vital effects generally, due to the large tracer gradients in individual corals living under relatively constant environmental conditions. Here we present stable isotope, minor and trace metal (Me/Ca ratios) data in a suite of modern Desmophyllum dianthus specimens, collected over multiple spatial scales in individual corals (bulk, micromill, SIMS, nanoSIMS). Spatially coherent $\mathrm{Me} / \mathrm{Ca}$ correlations are observed in the fibrous aragonite of individual corals, including positive correlations between $\mathrm{Mg} / \mathrm{Ca}, \mathrm{Li} / \mathrm{Ca}$ and $\mathrm{B} / \mathrm{Ca}$, as well as negative correlations between $\mathrm{Mg} / \mathrm{Ca}$ and $\mathrm{Sr} / \mathrm{Ca}$, consistent with previous studies. We also for the first time document strong correlations between the isotopic $\left(\delta^{18} \mathrm{O}\right.$ and $\left.\delta^{13} \mathrm{C}\right)$ and elemental compositions of the skeletons, most notably a negative correlation between $\delta^{18} \mathrm{O}$ and $\mathrm{Mg} / \mathrm{Ca}$ and a positive correlation between $\delta^{18} \mathrm{O}$ and $\mathrm{U} / \mathrm{Ca}$. The centers of calcification (COCs) in the coral skeletons show distinct tracer correlations from the fibrous aragonite. We interpret the spatially coherent tracer correlations in deep-sea corals with a numerical model of coral calcification previously developd for the stable isotopes that considers the role of the enzyme carbonic anhydrase in the calcification processs. With the carbonate chemistry in the model constrained by the stable isotope data, we are able to explain the observed $\mathrm{Me} / \mathrm{Ca}$ correlations as well as their range of variability, as a result of internal $\mathrm{pH}$ elevation in the extracellular calcifying fluid (ECF) of the corals with limited Ca-pumping through the membrane. In particular, the positive $\mathrm{Mg} / \mathrm{Ca}-\mathrm{B} / \mathrm{Ca}$ correlation in the secondary aragonite suggests a borate $\left(\mathrm{B}(\mathrm{OH})_{4}^{-}\right)$for carbonate ion $\left(\mathrm{CO}_{3}{ }^{2-}\right)$ incorporation mechanism in biogenic aragonite. In addition, we find a reduction in tracer variability in corals from undersaturated seawater as opposed to their counterparts from supersaturated conditions, suggesting a limited amount of internal $\mathrm{pH}$ elevation in response to the environmental stress. 